\title{
Genetic diversity and differentiation in Chinese sour cherry Prunus pseudocerasus Lindl., and its implications for conservation
}

\author{
Miao-Miao Li · Yu-Liang Cai · Zeng-Qiang Qian • \\ Gui-Fang Zhao
}

Received: 11 June 2008/Accepted: 4 September 2008/Published online: 21 October 2008

(C) Springer Science+Business Media B.V. 2008

\begin{abstract}
In this study, the genetic diversity and differentiation of 10 natural Prunus pseudocerasus Lindl. populations were investigated using intersimple sequence repeat (ISSR) markers. Totally, 18 selected primers generated 150 loci, with an average of 8.33 bands per primer. The results showed that the percentage of polymorphic bands $(P P B)$ was pretty low at the population level $(P P B=1.13-32 \%)$, but relatively high at the species level $(P P B=84 \%)$. Besides, a high level of genetic differentiation among populations was detected based on the gene differentiation coefficient $\left(G_{\mathrm{ST}}=0.7118\right)$ and the hierarchical analysis of molecular variance (AMOVA) $\left(\Phi_{\mathrm{ST}}=64.53 \%, P<0.001\right)$, in line with the low inter-population gene flow $\left(N_{\mathrm{m}}=0.2025\right)$. Moreover, Mantel test revealed a significant correlation between genetic and geographic distances among the
\end{abstract}

M.-M. Li · G.-F. Zhao ( $₫)$

Key Laboratory of Resource Biology and Biotechnology in Western China (Ministry of Education), College of Life Sciences, Northwest University, Xian 710069, People's Republic of China

e-mail: guifang.zhao@gmail.com

Y.-L. Cai

College of Horticulture, Northwest A \& F University, Yangling 712100, People's Republic of China

Z.-Q. Qian

School of Marine and Tropical Biology and Comparative Genomics Centre, James Cook University, Townsville,

QLD 4811, Australia populations $(r=0.5272, P<0.005)$. The high level of intraspecific genetic diversity was probably related with its life history traits, while its small population size and the resultant high levels of genetic drift and inbreeding might explain the low genetic diversity within populations. The relatively high inter-population genetic differentiation was largely attributed to its small population size, habitat fragmentation, the mode of pollen and seed dispersal, and geographic isolation. Based on the present study, conservation strategies were proposed to preserve this valuable natural germplasm resource.

Keywords Cherry - Genetic differentiation Genetic diversity - Inter-simple sequence repeats (ISSRs) · Prunus pseudocerasus Lindl.

\section{Introduction}

As a fundamental component of biodiversity, genetic diversity is essential to the long-term survival of any species, especially in environments which are subject to climate changes or the introduction of new pests, pathogens or competitors (Rajora and Mosseler 2001). Reduced genetic diversity usually has deleterious effects on species fitness, e.g. an increased risk of inbreeding effects, and may threaten the survival of species or populations (Malone et al. 2003; Reed and Frankham 2003). Thus, an accurate estimate of genetic diversity of the targeted species 
or populations is essential to the effective conservation and utilization of genetic resources.

Prunus pseudocerasus Lindl., commonly known as Chinese sour cherry, is an insect-pollinated, perennial species with a long history of cultivation, and belongs to the family Rosaceae, genus Prunus, subgenus Cerasus. It originates from Southwest China and is widely distributed in the temperate zone of Northern Hemisphere, occurring along the south slope of mountains or ditch sides ( $\mathrm{Yu}$ and $\mathrm{Li} \mathrm{1986).} \mathrm{The} \mathrm{fruit}$ of $P$. pseudocerasus contains rich nutritional ingredients and trace elements, such as proteins, carotene, Vitamin C, saccharides, iron and phosphorus ( $\mathrm{Yu}$ and $\mathrm{Li}$ 1986). It is also a widely used material for the cultivation of new cherry cultivars (Ochatt et al. 1987; Gutièrrez-Pesce et al. 1998; Mandegaran et al. 1999; Pesce and Rugini 2004). To adapt to ecologically diverse habitats, it has accumulated considerable genetic variations associated with various characters of great value for the fruit farming. In addition, its flower, leaf, root, bark and core are of high medicinal value. Because of its economic values, it has been playing an important role in fruit industry. However, as indicated by our field survey in 2002 and 2003, largely due to anthropogenic activities (e.g. road construction, deforestation and grazing), its natural germplasm resource has been seriously devastated and needs urgent preservation and restoration. To date, all previous studies of $P$. pseudocerasus have mainly been focused on its taxonomy (Chang et al. 2007), propagation (Feucht and Dausend 1976; Chen et al. 2003), morphology (Chu et al. 1995; Xin et al. 1996), phylogeography (Cao et al. 2007), phytochemistry (Gao et al. 2003; Takahashi et al. 2006; Sun 2007) and physiology (Atkinson and Taylor 1996; Zhao et al. 2005). No efforts have been reported on its genetic diversity and structure.

Genetic markers have contributed to the study of plant evolutionary ecology by providing methods for detecting genetic differences among individuals (Cruzan 1998). During the past decades, their popularity has enabled the significant progresses in understanding the population genetics of plant species. Among these marker systems, inter-simple sequence repeats (ISSRs) are a microsatellite-derived genetic finger printing method based on the amplification of the specific regions between two SSR (simple sequence repeat) sequences (Zietkiewicz et al. 1994). Practically, due to the longer SSR-based primers, ISSRs enable higher-stringency DNA amplifications and can yield stable and reproducible bands (Wolfe et al. 1998), and has already established wide applications in studies of genetic diversity, phylogenetics, genetic mapping and evolutionary biology in a wide range of plant species (e.g. Qiu et al. 2004; Zhang et al. 2006; Chennaoui-Kourda et al. 2007; Li and Jin 2007).

In the present study, we investigated ISSR markers in 10 natural populations of $P$. pseudocerasus. The aims were to: (1) characterize its genetic diversity at both population and species levels; (2) reveal the partitioning of genetic variation within and among populations; and (3) eventually provide some references for its practical conservation strategies and resource exploitation.

\section{Materials and methods}

Plant materials and DNA extraction

Eighty individuals, which corresponded to $10 \mathrm{popu}-$ lations, were sampled across five provinces in China, including Shaanxi, Sichuan, Chongqing, Guizhou and Yunnan (Table 1; Fig.1). Young leaves were collected, dried in a plastic bag with silica gel, transported to the laboratory and stored in $-80^{\circ} \mathrm{C}$ freezer until use. Corresponding to each population, parameters such as longitude, latitude and altitude were determined and recorded for further analysis.

Total genomic DNA was extracted from dried leaves using a modified CTAB method (Wang and Fang 1998). Then, the DNA extract was suspended in $200 \mu \mathrm{l} 0.1 \times \mathrm{TE}$ buffer $(10 \mathrm{mM} \mathrm{pH} 8.0$ Tris- $\mathrm{HCl}$; $1 \mathrm{mM}$ pH 8.0 EDTA), and kept at $-20^{\circ} \mathrm{C}$ for longterm storage or at $4^{\circ} \mathrm{C}$ for immediate use.

\section{ISSR-PCR amplification}

One hundred primers (UBC Primer Set \#9, Biotechnology Laboratory, University of British Columbia, Canada) were initially screened, and 18 primers, which yielded bright and reproducible bands, were obtained and used for the further analysis of all eighty DNA samples (Table 2).

PCR was performed in a $10-\mu$ reaction volume containing $50 \mathrm{ng}$ of genomic DNA, $2 \mathrm{mM} \mathrm{MgCl}$, $0.2 \mathrm{mM}$ dNTPs, $0.75 \mathrm{U}$ Taq polymerase and $1 \mu \mathrm{M}$ 
Table 1 Locations and sample sizes of Prunus pseudocerasus populations in this study

Fig. 1 Sampling locations of the $10 P$. pseudocerasus populations in China

\begin{tabular}{lllllc}
\hline Populations & Sampling locations & $\begin{array}{l}\text { Longitude } \\
\left({ }^{\circ} \mathrm{E}\right)\end{array}$ & $\begin{array}{l}\text { Latitude } \\
\left({ }^{\circ} \mathrm{N}\right)\end{array}$ & $\begin{array}{l}\text { Altitude } \\
(\mathrm{m})\end{array}$ & $\begin{array}{l}\text { Sample } \\
\text { size }\end{array}$ \\
\hline YJ & $\begin{array}{l}\text { Yinjiang, Guizhou } \\
\text { Province }\end{array}$ & $108^{\circ} 36^{\prime}$ & $27^{\circ} 55^{\prime}$ & 917 & 8 \\
YN & $\begin{array}{l}\text { Heilongtan, Yunnan } \\
\text { Province }\end{array}$ & $102^{\circ} 54^{\prime}$ & $25^{\circ} 02^{\prime}$ & 1,923 & 8 \\
& Mengzi, Yunnan Province & $103^{\circ} 47^{\prime}$ & $23^{\circ} 24^{\prime}$ & 1,902 & 7 \\
MZ & Pingbian, Yunnan Province & $103^{\circ} 52^{\prime}$ & $23^{\circ} 13^{\prime}$ & 2,019 & 3 \\
PB & Wolong, Sichuan Province & $103^{\circ} 13^{\prime}$ & $31^{\circ} 04^{\prime}$ & 1,950 & 3 \\
WL & Baoxing, Sichuan Province & $102^{\circ} 45^{\prime}$ & $30^{\circ} 30^{\prime}$ & 1,950 & 5 \\
BX & Chengkou, Chongqing & $108^{\circ} 43^{\prime}$ & $32^{\circ} 03^{\prime}$ & 1,248 & 14 \\
CK & Foping, Shaanxi Province & $107^{\circ} 48^{\prime}$ & $33^{\circ} 34^{\prime}$ & 1,346 & 17 \\
FP & Xixiang, Shaanxi Province & $108^{\circ} 15^{\prime}$ & $33^{\circ} 45^{\prime}$ & 1,616 & 6 \\
XX & Ankang, Shaanxi Province & $108^{\circ} 53^{\prime}$ & $32^{\circ} 09^{\prime}$ & 820 & 9 \\
AK & & & &
\end{tabular}

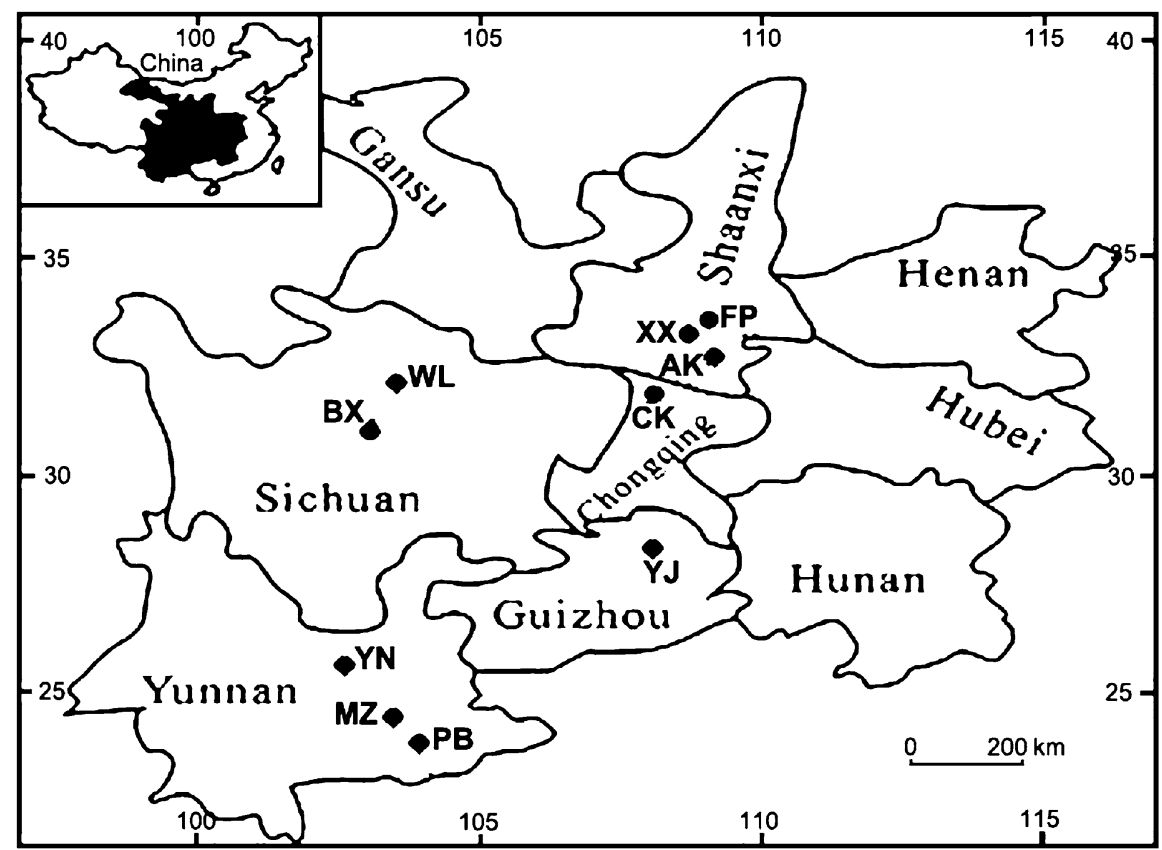

primers. The amplifications were performed in the thermal cycler PTC-200 (MJ Research) with the following program: initial denaturation at $94^{\circ} \mathrm{C}$ for $2 \mathrm{~min}$; followed by 35 cycles of $94^{\circ} \mathrm{C}$ for $30 \mathrm{~s}$, appropriate annealing temperature (see Table 2 for details) for $45 \mathrm{~s}, 72^{\circ} \mathrm{C}$ for $90 \mathrm{~s}$; and last synthesis at $72^{\circ} \mathrm{C}$ for $7 \mathrm{~min}$.

Amplified products were electrophoresed in 2\% agarose gel at $100 \mathrm{~V}$ for $1.5 \mathrm{~h}$ along with the molecular weight marker GeneRuler DL2000
(Shanghai Sangon Biological Engineering Technology \& Service Co., Ltd, China), stained with ethidium bromide, and photographed with Bio-RAD Gel Documentation System.

Statistical analysis

Since ISSR markers were dominantly inherited, we assumed that each band represented the phenotype at a single biallelic locus (Williams et al. 1990). 
Table 2 ISSR primers used in this study

\begin{tabular}{|c|c|c|c|c|}
\hline Primer code & Sequence $\left(5^{\prime} \rightarrow 3^{\prime}\right)$ & $N_{\mathrm{L}}$ & $\begin{array}{l}\text { Size range } \\
\text { (bp) }\end{array}$ & $T_{\mathrm{A}}\left({ }^{\circ} \mathrm{C}\right)$ \\
\hline UBC813 & $(\mathrm{CT})_{8} \mathrm{~T}$ & 7 & $448-1,545$ & 52 \\
\hline UBC816 & $(\mathrm{CA})_{8} \mathrm{~T}$ & 7 & $312-1,753$ & 52 \\
\hline UBC822 & $(\mathrm{TC})_{8} \mathrm{~A}$ & 6 & $459-1,062$ & 56 \\
\hline UBC824 & $(\mathrm{TC})_{8} \mathrm{G}$ & 8 & $322-1,823$ & 52 \\
\hline UBC827 & $(\mathrm{AC})_{8} \mathrm{G}$ & 9 & $234-1,753$ & 52 \\
\hline UBC850 & $(\mathrm{GT})_{8} \mathrm{YC}$ & 5 & $720-1,663$ & 52 \\
\hline UBC853 & $(\mathrm{TC})_{8} \mathrm{RT}$ & 11 & $252-1,800$ & 52 \\
\hline UBC854 & $(\mathrm{TC})_{8} \mathrm{RG}$ & 11 & $287-1,401$ & 50 \\
\hline UBC857 & $(\mathrm{AC})_{8} \mathrm{YG}$ & 7 & $281-1,458$ & 55 \\
\hline UBC866 & $(\mathrm{CTC})_{6}$ & 4 & $592-1,414$ & 57 \\
\hline UBC868 & $(\mathrm{GAA})_{6}$ & 8 & $373-1,868$ & 57 \\
\hline UBC873 & $(\mathrm{GACA})_{4}$ & 11 & $337-1,986$ & 56 \\
\hline UBC878 & $(\mathrm{GGAT})_{4}$ & 8 & $647-1,882$ & 56 \\
\hline UBC880 & $(\mathrm{GGAGA})_{3}$ & 13 & $231-1,378$ & 55 \\
\hline UBC881 & $(\text { GGGTG })_{3}$ & 8 & $426-1,426$ & 50 \\
\hline UBC892 & TAGATCTGATATCTGAATTCCC & 6 & $553-1,500$ & 52 \\
\hline UBC893 & NNNNNNNNNNNNNNN & 8 & $390-1,815$ & 52 \\
\hline UBC899 & CATGGTGTTGGTCATTGTTCCA & 13 & $308-1,752$ & 55 \\
\hline
\end{tabular}

$\mathrm{N}=(\mathrm{A}, \mathrm{G}, \mathrm{C}, \mathrm{T}) ; \mathrm{R}=(\mathrm{A}$,

$\mathrm{G}) ; \mathrm{Y}=(\mathrm{C}, \mathrm{T}) ; N_{\mathrm{L}}$, number of loci scored; $T_{\mathrm{A}}$, annealing temperature $\left({ }^{\circ} \mathrm{C}\right)$ correlation between inter-population genetic and geographic distance matrices.

\section{Results}

Genetic diversity

The 18 selected primers generated 150 bands ranging in size from 231 to $1,986 \mathrm{bp}$, corresponding to an average of 8.33 bands per primer (Table 2). At the population level, the percentage of polymorphic bands $(P P B)$ varied between $1.33 \%$ and $32.00 \%$, with an average of $18.67 \%$, while the value rose sharply to $84.00 \%$ at the species level. Table 3 showed the details about Nei's gene diversity index $(h)$ and Shannon's information index $(I)$. As indicated by these three parameters, the highest level of variability occurred in Population YJ $\quad(P P B=32.00 \% ; \quad h=0.1092$; $I=0.1643)$, whereas the lowest level in Population $\mathrm{WL}(P P B=1.33 \% ; h=0.0065 ; I=0.0091)$.

Genetic structure

POPGENE analysis revealed that the gene differentiation coefficient among populations $\left(G_{\mathrm{ST}}\right)$ was 
Table 3 Genetic diversity of $P$. pseudocerasus detected by ISSR analysis

\begin{tabular}{llllll}
\hline Populations & $n_{\mathrm{a}}$ & $n_{\mathrm{e}}$ & $h$ & $I$ & $P P B(\%)$ \\
\hline YJ & 1.3200 & 1.1848 & 0.1092 & 0.1643 & 32.00 \\
YN & 1.2667 & 1.1730 & 0.0986 & 0.1459 & 26.67 \\
MZ & 1.1467 & 1.0867 & 0.0502 & 0.0755 & 14.67 \\
PB & 1.0800 & 1.0552 & 0.0315 & 0.0463 & 8.00 \\
WL & 1.0133 & 1.0127 & 0.0065 & 0.0091 & 1.33 \\
BX & 1.1189 & 1.0871 & 0.0471 & 0.0684 & 11.33 \\
CK & 1.2867 & 1.1592 & 0.0933 & 0.1408 & 28.67 \\
FP & 1.2533 & 1.1369 & 0.0819 & 0.1244 & 25.33 \\
XX & 1.2667 & 1.1715 & 0.0986 & 0.1462 & 26.67 \\
AK & 1.1200 & 1.0742 & 0.0438 & 0.0653 & 12.00 \\
Mean value & 1.1872 & 1.1141 & 0.0661 & 0.0986 & 18.67 \\
At species level & 1.8400 & 1.3648 & 0.2242 & 0.3479 & 84.00 \\
\hline
\end{tabular}

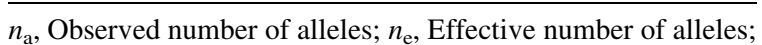
$h$, Nei's gene diversity; $I$, Shannon's information index; $P P B$, Percentage of polymorphic bands (\%)

0.7118, while AMOVA analysis showed that $64.53 \%$ of total variance occurred among populations (Table 4), both of which indicated a high level of inter-population genetic differentiation. This was further confirmed by the low level of gene flow $\left(N_{\mathrm{m}}=0.2025\right)$ among populations.

Nei's (1978) unbiased genetic distances among populations were calculated based on 150 markers scored. Values ranged from 0.0796 (PB vs. WL) to 0.3472 (YN vs. MZ) (Table 5). Based on the obtained distance matrix, cluster analysis (UPGMA) was performed to further reveal the genetic relationships among populations. The 10 populations were clustered into two groups (Fig. 2). Group I was further subdivided into three subgroups: one including Population FP, XX and AK, one including Population $\mathrm{YJ}$ and $\mathrm{CK}$, and the remainder including Population $\mathrm{PB}, \mathrm{YN}$ and MZ. Group II comprised two populations (WL \& BX), both of which were sampled from Sichuan Province. This topology was basically consistent with the geographic distribution of these populations, indicating a possible correlation.
In addition, Mantel test revealed a significant correlation between geographic and genetic distances among populations $(r=0.5272, P<0.005)$.

\section{Discussion}

Effects of sample size on population genetics parameters

Since individuals of $P$. pseudocerasus usually occurred sporadically in small populations or over relatively wide areas, sample sizes of some populations in this study were pretty small. For example, only three individuals were observed in Population $\mathrm{PB}$ and WL, respectively. This inevitably raised doubts about the validity of the conclusions for these small populations.

Nei and Roychoudhury (1974) concluded that far more information can be obtained in an electrophoretic study by increasing the number of loci rather than the number of individuals. This was later empirically confirmed by Gorman and Renzi (1979), who demonstrated that both heterozygosity and genetic distance estimates are more significantly affected by the number of loci sampled than by the number of individuals sampled. Studies involving estimates of genetic distance are relatively sample size independent, and even a sample of two individuals usually yields a heterozygosity estimate within $2.5 \%$ of the $\%$ heterozygosity calculated for a much larger sample if a sufficient number of loci are examined (Gorman and Renzi 1979). Thus, despite the small sample sizes of some populations, the population genetics parameters calculated in this study can still hold true.

\section{Genetic diversity of $P$. pseudocerasus}

Our ISSR assay of the ten $P$. pseudocerasus populations revealed a relatively high $P P B$ value $(84.00 \%)$ at the species level, which was higher than those observed in other species in the family Rosaceae, e.g.

Table 4 Analysis of molecular variance (AMOVA) within/among P. pseudocerasus populations

\begin{tabular}{lrrrrrr}
\hline Source of variance & df & SSD & MSD & Variance component & Ratio of variance $(\%)$ & $P$ \\
\hline Among populations & 9 & 1071.97 & 101.670 & 12.254 & 64.53 & $<0.001$ \\
Within populations & 70 & 503.68 & 6.735 & 6.735 & 35.47 & $<0.001$ \\
\hline
\end{tabular}


Table 5 Nei's (1978) unbiased genetic identity (above diagonal) and genetic distance (below diagonal) among P. pseudocerasus populations

\begin{tabular}{lllllllllll}
\hline Populations & YJ & YN & MZ & PB & WL & BX & CK & FP & XX & AK \\
\hline YJ & $* * * *$ & 0.8446 & 0.8469 & 0.8103 & 0.8000 & 0.8492 & 0.8801 & 0.8080 & 0.8397 & 0.7781 \\
YN & 0.1689 & $* * * *$ & 0.9234 & 0.8492 & 0.7313 & 0.7779 & 0.8318 & 0.7911 & 0.8004 & 0.8108 \\
MZ & 0.1661 & 0.0796 & $* * * *$ & 0.8813 & 0.7242 & 0.7692 & 0.7922 & 0.7667 & 0.8283 & 0.7890 \\
PB & 0.2104 & 0.1635 & 0.1264 & $* * * *$ & 0.7067 & 0.7082 & 0.7699 & 0.7435 & 0.8124 & 0.7476 \\
WL & 0.2232 & 0.3130 & 0.3227 & 0.3472 & $* * * *$ & 0.8626 & 0.7971 & 0.7894 & 0.7717 & 0.7244 \\
BX & 0.1635 & 0.2511 & 0.2625 & 0.3451 & 0.1478 & $* * * *$ & 0.8121 & 0.7608 & 0.7507 & 0.7394 \\
CK & 0.1278 & 0.1842 & 0.2329 & 0.2615 & 0.2268 & 0.2082 & $* * * *$ & 0.8657 & 0.8355 & 0.8517 \\
FP & 0.2132 & 0.2344 & 0.2656 & 0.2964 & 0.2365 & 0.2734 & 0.1442 & $* * * *$ & 0.8708 & 0.8300 \\
XX & 0.1748 & 0.2227 & 0.1883 & 0.2078 & 0.2591 & 0.2867 & 0.1797 & 0.1383 & $* * * *$ & 0.8441 \\
AK & 0.2509 & 0.2097 & 0.2370 & 0.2909 & 0.3225 & 0.3019 & 0.1606 & 0.1864 & 0.1695 & $* * * *$ \\
\hline
\end{tabular}

Fig. 2 UPGMA

dendrogram for the $10 P$. pseudocerasus populations based on Nei's (1978) genetic distance

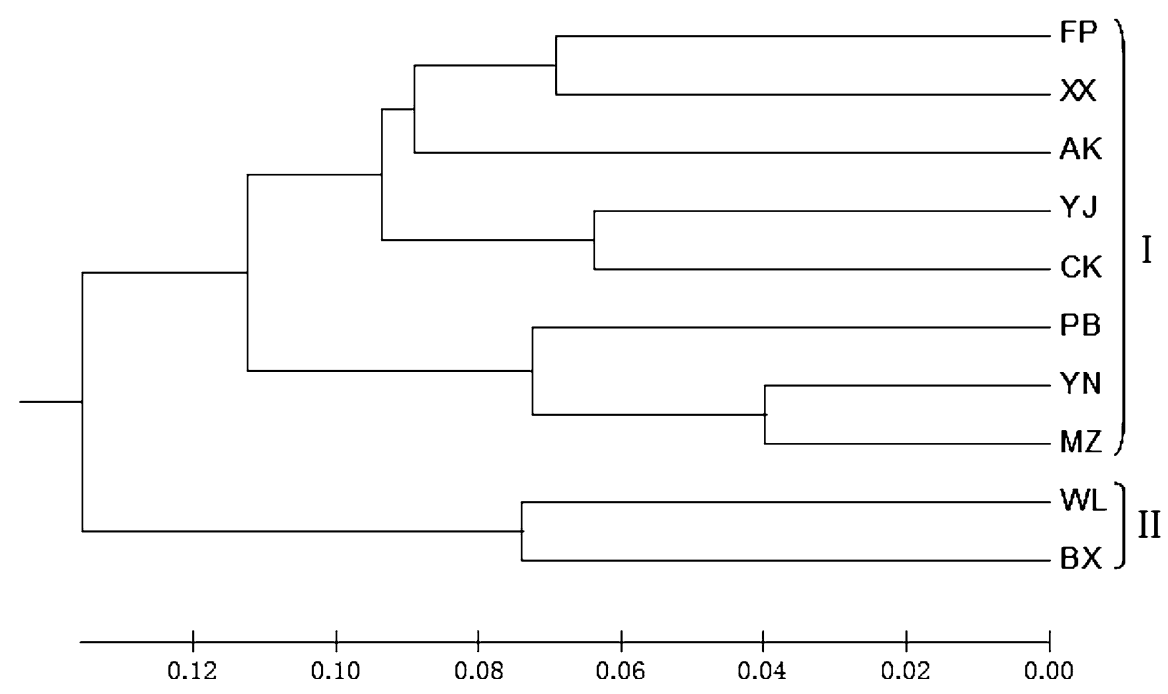

$79.78 \%$ in Prunus persica (L.) Batsch (Wang et al. 2001) and $76.2 \%$ in Prunus mume Sieb. et Zucc. (Zhang and Bao 2007). In contrast, the genetic diversity within populations was pretty low (PPB: $1.33 \sim 32.00 \%$; Average: 18.67\%).

This high level of intraspecific genetic diversity was probably linked with its life history traits. It is now well documented that the level of genetic diversity may be attributed to several life history traits, such as geographic range, seed dispersal mechanism, mating system, life form and taxonomic status (Hamrick and Godt 1989). Generally, woody species with large geographic ranges, outcrossing breeding systems, and wind or animal-ingested seed dispersal have more genetic diversity within species than woody species with other combinations of traits (Hamrick et al. 1992), basically in line with the traits of $P$. pseudocerasus. As a long-lived perennial woody plant, $P$. pseudocerasus is widely distributed in the temperate zone of Northern Hemisphere (Yu and $\mathrm{Li}$ 1986). To adapt to ecologically diverse habitats, it has probably accumulated considerable genetic variation within species. Besides, it adopts a animal-ingested seed dispersal system (Cai 2006). Despite the poor knowledge about its breeding system, all these traits together have probably resulted in its present high genetic diversity at the species level.

On the other hand, this study also revealed a pretty low level of genetic diversity within population, which could be largely explained by its small population size, the effects of genetic drift and probably of inbreeding. Small populations tend to have increased levels of genetic drift, which can be 
enforced by high incidences of inbreeding, and the resultant loss of genetic diversity (Thingsgaard 2001; Mateu-Andrés and Segarra-Moragues 2003). According to our field survey, $P$. pseudocerasus usually occurred in fragmented habitats, and most of its populations had a very small size. In consequence, genetic drift predominated, and resulted in increased homozygosity and loss of genetic variability. Despite the unavailability of definite records, $P$. pseudocerasus has probably adopted a facultative breeding system (i.e. the coexistence of self-pollination and cross-pollination) since self-compatibility was previously reported (Li et al. 2007).

\section{Genetic structure}

Population genetic structure reflects the interactions among species' long-term evolutionary history (e.g. habitat fragmentation, population specialization), mutation, recombination, genetic drift, breeding system, gene flow and natural selection (Slatkin 1987; Schaal et al. 1998). In this study, a high level of genetic differentiation $\left(G_{\mathrm{ST}}=0.7118 ; \Phi_{\mathrm{ST}}=64.53 \%\right)$ and pretty low gene flow $\left(N_{\mathrm{m}}=0.2025\right)$ were revealed among $P$. pseudocerasus populations. Typically, $N_{\mathrm{m}}<1$ indicates strong differential selection, in which case population differentiation may be maintained (Slatkin 1985).

The present high level of inter-population genetic differentiation could be largely attributed to several factors. Firstly, it was probably closely connected with its small population size and habitat fragmentation. The theory of population genetics indicates that genetic differentiation caused by genetic drift and inbreeding depression should increase in progressively smaller and isolated populations (Templeton et al. 1990), as supported by previous reports (Buza et al. 2000; Shea and Furnier 2002; Tomimatsu and Ohara 2003). Despite its wide geographic distribution, the habitats of $P$. pseudocerasus were fragmented into small patches largely due to geographic barriers and anthropogenic activities, and the sizes of the isolated populations, e.g. Population PB and WL, were usually pretty small. As a result of habitat fragmentation, these populations may have accumulated considerable 'localized' genetic variations, which help adapt themselves to their specific local environments and distinguish themselves from others. Secondly, the mode of pollen and seed dispersal, which determines the gene flow among populations ( $\mathrm{Li}$ and Chen 2004), may partly account for this high level of genetic differentiation. Flowers of $P$. pseudocerasus are mainly pollinated by insects (e.g. bees), which usually have a limited range of flight (Cai 2006), while natural populations of $P$. pseudocerasus usually occur in discrete mountainous regions with varying physical conditions (e.g. topography, altitude, humidity and temperature). Different physical conditions can lead to fruit ripening and flowering asynchrony, the latter of which in turn results in the substantial decrease or even lack of gene flow via pollen dispersal. Also, for the animal-ingested seed dispersal system, its efficiency largely depends on the migration habits and capacity of animals. Especially for those obligate fruit-eaters, which feed mainly or solely on the fruit of $P$. pseudocerasus during the ripening period, when fruit ripening asynchrony occurs, they may confine their activities within the areas where ripe fruits are available. As a result, the seed exchange among $P$. pseudocerasus populations will be discounted. Thirdly, Mantel test revealed a significant correlation between geographic and genetic distances ( $r=0.5272, P<0.005$ ), indicating the role of geographic isolation as an important factor in the evolution of $P$. pseudocerasus' genetic structure. In addition, other factors, such as the low seed germination rate and breeding system (probably the coexistence of selfpollination and cross-pollination), may also partly contribute to the present population genetic structure in P. pseudocerasus.

\section{Conservation considerations}

The level and partitioning of genetic diversity are likely to affect the evolutionary potential of species and/or populations (Futuyma 1986). And, the main objective in any plant genetic resources conservation program should be to maintain the highest possible level of genetic variability present across the gene pool of a given species or crop both in its natural range and in a germplasm collection. As revealed in this study, the most immediate threat to P. pseudocerasus appears to be the genetic drift and inbreeding depression, and anthropogenic activities should take major responsibility for the reduction in population size.

An effective conservation strategy should integrate different conservation actions, "which together leads to an optimum sustainable use of genetic diversity 
existing in a target gene pool, in the present and future' (IPGRI 1993). To preserve this valuable natural germplasm resource, the following measures are proposed. Firstly, efforts should be made to protect its natural habitats. According to our field survey, the habitats of $P$. pseudocerasus have been seriously deteriorated and fragmented largely due to anthropogenic activities, such as road construction, deforestation and grazing. In consequence, these populations usually have a pretty small size, and thus tend to have increased levels of genetic drift and inbreeding depression. However, the conflict between conservation and local interests is a difficult issue. And also for the economic reasons, we suggest the emphasis for in situ conservation be placed on populations with high genetic diversity, such as Population YJ, CK, YN, $\mathrm{XX}$ and FP. Especially, Population FP, with the biggest size and relatively high genetic diversity, is located in a national nature reserve, and thus deserves more attention. Secondly, ex situ conservation should be a good complement to the in situ measures. Translocations are becoming increasingly popular since they are effective in both removing detrimental variation associated with inbreeding depression as well as restoring neutral genetic variation to historical levels (Bouzat et al. 2008). Seeds can be collected and exchanged among populations, so that they can increase their sizes and genetic diversity by natural regeneration. Thirdly, an appropriate number of seeds can be sampled from all these populations, and either be stored in a gene bank (e.g. seed bank, germplasm bank) or be used for the establishment of artificial populations in appropriate sites or botanical gardens. Besides, new techniques or methods should be developed to promote its applications in fruit industry, which will in turn benefit its conservation.

Acknowledgements This study was financially co-supported by the National Hi-Tech Research and Developement Program of China (2006AA100108-4-21), Project 948 of the State Forestry Administration of China (2005-4-46) and the International Sci-Tech Cooperation Program of the Ministry of Science and Technology of China (CHN-8/2006).

\section{References}

Atkinson CJ, Taylor JM (1996) Effects of elevated $\mathrm{CO}_{2}$ on stem growth, vessel area and hydraulic conductivity of oak and cherry seedlings. New Phytol 133:617-626. doi: 10.1111/j.1469-8137.1996.tb01930.x
Bouzat J, Johnson J, Toepfer J, Simpson S, Esker T, Westemeier $\mathrm{R}$ (2008) Beyond the beneficial effects of translocations as an effective tool for the genetic restoration of isolated populations. Conserv Genet. doi:10.1007/s10592-1000819547-10598

Buza L, Young A, Thrall P (2000) Genetic erosion, inbreeding and reduced fitness in fragmented populations of the endangered tetraploid pea Swainsona recta. Biol Conserv 93:177-186. doi:10.1016/S0006-3207(99)00150-0

Cai Y-L (2006) Genetic analysis of the wild cherry germplasm and identification of cultivated cherry varieties using DNA fingerprints. In: College of Life Sciences. Northwest University, Xi'an (Shaanxi, China), p 100

Cao D-W, Cai Y-L, Yang J, Zhao G-F (2007) PCR-RFLP analysis of Prunus pseudocerasus. J Northwest A \& F Univ (Nat Sci Ed) 35:173-178

Chang K-S, Chang C-S, Park TY, Roh MS (2007) Reconsideration of the Prunus serrulata complex (Rosaceae) and related taxa in eastern Asia. Bot J Linn Soc 154:35-54. doi:10.1111/j.1095-8339.2007.00631.x

Chen J, Li Q, Sun Z (2003) Study on shoot-tip culture of Prunus pseudocerasus. Acta Hortic Sin 30:317-318

Chennaoui-Kourda H, Marghali S, Marrakchi M, Trifi-Farah N (2007) Genetic diversity of Sulla genus (Hedysarea) and related species using inter-simple sequence repeat (ISSR) markers. Biochem Syst Ecol 35:682-688. doi:10.1016/ j.bse.2007.05.005

Chu Q, Cao Y, Sun C, Zhang X (1995) Anatomy studies on the dwarfing characters of stem and leaf of dwarf cherry. $J$ Laiyang Agric Coll 12:237-241

Cruzan MB (1998) Genetic markers in plant evolutionary ecology. Ecology 79:400-412

Excoffier L, Smouse PE, Quattro JM (1992) Analysis of molecular variance inferred from metric distances among DNA haplotypes: application to human mitochondrial DNA restriction data. Genetics 131:479-491

Feucht W, Dausend B (1976) Root induction in vitro of easyto-root Prunus pseudocerasus and difficult-to-root Prunus avium. Sci Hortic (Amsterdam) 4:49-54. doi:10.1016/ 0304-4238(76)90064-9

Futuyma DJ (1986) Evolutionary biology, 2nd edn. Sinauer Associates, Sunderland, MA, USA

Gao H, Zhao L, Hu X, Sun L (2003) Study on the extraction and stability of cherry pigment. Food Ferment Ind 29: $54-57$

Gorman GC, Renzi J (1979) Genetic distance and heterozygosity estimates in electrophoretic studies: effects of sample size. Copeia 1979:242-249. doi:10.2307/1443409

Gutièrrez-Pesce P, Taylor K, Muleo R, Rugini E (1998) Somatic embryogenesis and shoot regeneration from transgenic roots of the cherry rootstock Colt (Prunus avium $\times$ P. pseudocerasus) mediated by $\mathrm{pRi} 1855 \mathrm{~T}$ DNA of Agrobacterium rhizogenes. Plant Cell Rep 17: 574-580. doi:10.1007/s002990050445

Hamrick JL, Godt MJW (1989) Allozyme diversity in plant species. In: Brown AHD, Clegg MT, Kahler AL, Weir BS (eds) Plant population genetics breeding and germplasm resources. Sinauer, Sunderland, MA, pp 43-63

Hamrick JL, Godt MJW, Sherman-Broyles SL (1992) Factors influencing levels of genetic diversity in woody plant species. New For 6:95-124. doi:10.1007/BF00120641 
IPGRI (1993) Diversity for development - The strategy of the International Plant Genetic Resources Institute. IPGRI, Rome, p 66

Kumar S, Tamura K, Nei M (2004) MEGA3: integrated software for molecular evolutionary genetics analysis and sequence alignment. Brief Bioinform 5:150-163. doi: $10.1093 / \mathrm{bib} / 5.2 .150$

Li H-S, Chen G-Z (2004) Genetic diversity of mangrove plant Sonneratia caseolaris in Hainan Island based on ISSR analysis. Acta Ecol Sin 24:1657-1663

Li J, Jin Z (2007) Genetic variation and differentiation in Torreya jackii Chun, an endangered plant endemic to China. Plant Sci 172:1048-1053. doi:10.1016/j.plantsci. 2007.02.009

Li X, Zhang S-L, Tao S-T, Wu H-Q, Wu J (2007) The differences of pollen germination and pollen tube growth between Chinese cherry and sweet cherry. Acta Bot Boreal-Occident Sin 27:429-434

Liedloff A (1999) Mantel (Version 2.0): mantel nonparametric test calculator. Queensland University of Technology, Brisbane, Australia

Malone CL, Knapp CR, Taylor JF, Davis SK (2003) Genetic consequences of Pleistocene fragmentation: isolation, drift, and loss of diversity in rock iguanas (Cyclura). Conserv Genet 4:1-15. doi:10.1023/A:1021885323539

Mandegaran Z, Roberts AV, Hammatt N (1999) The ability of Prunus avium $\times$ P. pseudocerasus 'Colt' to form somatic embryos in vitro contrasts with the recalcitrance of $P$. avium. Plant Cell Tissue Organ Cult 59:57-63. doi: 10.1023/A: 1006476627434

Mantel N (1967) The detection of disease clustering and a generalized regression approach. Cancer Res 27:209-220

Mateu-Andrés I, Segarra-Moragues JG (2003) Patterns of genetic diversity in related taxa of Antirrhinum $\mathrm{L}$ assessed using allozymes. Biol J Linn Soc Lond 79:299-307. doi: 10.1046/j.1095-8312.2003.00163.x

Nei M (1978) Estimation of average heterozygosity and genetic distance from a small number of individuals. Genetics 89:583-590

Nei M, Roychoudhury AK (1974) Sampling variances of heterozygosity and genetic distance. Genetics 76:379-390

Ochatt SJ, Cocking EC, Power JB (1987) Isolation, culture and plant regeneration of Colt cherry (Prunus avium $\times$ pseudocerasus) protoplasts. Plant Sci 50:139-143. doi: 10.1016/0168-9452(87)90150-6

Pesce PG, Rugini E (2004) Influence of plant growth regulators, carbon sources and iron on the cyclic secondary somatic embryogenesis and plant regeneration of transgenic cherry rootstock 'Colt' (Prunus avium $\times$ P. pseudocerasus). Plant Cell Tissue Organ Cult 79:223232. doi:10.1007/s11240-004-0663-y

Qiu Y-X, Hong D-Y, Fu C-X, Cameron KM (2004) Genetic variation in the endangered and endemic species Changium smyrnioides (Apiaceae). Biochem Syst Ecol 32:583596. doi:10.1016/j.bse.2003.08.004

Rajora OP, Mosseler A (2001) Challenges and opportunities for conservation of forest genetic resources. Euphytica 118:197-212. doi:10.1023/A:1004150525384

Reed DH, Frankham R (2003) Correlation between fitness and genetic diversity. Conserv Biol 17:230-237. doi:10.1046/ j.1523-1739.2003.01236.x
Schaal BA, Hayworth DA, Olsen KM, Rauscher JT, Smith WA (1998) Phylogeographic studies in plants: problems and prospects. Mol Ecol 7:465-474. doi:10.1046/j.1365-294x. 1998.00318.x

Shea KL, Furnier GR (2002) Genetic variation and population structure in central and isolated populations of balsam fir, Abies balsamea (Pinaceae). Am J Bot 89:783-791. doi: 10.3732/ajb.89.5.783

Slatkin M (1985) Gene flow in natural populations. Annu Rev Ecol Syst 16:393-430. doi:10.1146/annurev.ecolsys.16.1. 393

Slatkin M (1987) Gene flow and the geographic structure of natural populations. Science 236:787-792. doi:10.1126/ science. 3576198

Sun Y (2007) The studies on the chemical constituents from the leaves of Prunus pseudocerasus Lindl. Jilin University, Changchun (Jilin, China), p 50

Takahashi K, Tsutsumi Y, Ohtani H, Katsuki T (2006) Variation of fragrance constituents in the leaves of Prunus. Biochem Syst Ecol 34:127-135. doi:10.1016/j.bse.2005. 07.022

Templeton AR, Shaw K, Routman E, Davis SK (1990) The genetic consequences of habitat fragmentation. Ann Mo Bot Gard 77:13-27. doi:10.2307/2399621

Thingsgaard K (2001) Population structure and genetic diversity of the amphiatlantic haploid peatmoss Sphagnum affine (Sphagnopsida). Heredity 87:485-496. doi:10.1046/ j.1365-2540.2001.00939.x

Tomimatsu H, Ohara M (2003) Genetic diversity and local population structure of fragmented populations of Trillium camschatcense (Trilliaceae). Biol Conserv 109:249-258. doi:10.1016/S0006-3207(02)00153-2

Wang G-L, Fang H-Y (1998) Plant gene engineering: principles and techniques. Science Press, Beijing

Wang P-W, Liu H-Z, Chen Y-Q, Jin X-L, Qu B-H (2001) RAPD analysis of germplasm resources in Pyrus. Acta Hortic Sin 28:460-462

Williams JGK, Kubelik AR, Livak KJ, Rafalski JA, Tingey SV (1990) DNA polymorphisms amplified by arbitrary primers are useful as genetic markers. Nucleic Acids Res 18:6531-6535. doi:10.1093/nar/18.22.6531

Wolfe AD, Xiang Q-Y, Kephart SR (1998) Assessing hybridization in natural populations of Penstemon (Scrophulariaceae) using hypervariable intersimple sequence repeat (ISSR) bands. Mol Ecol 7:1107-1125. doi:10.1046/j.1365-294x. 1998.00425.x

Xin Y, Si L, Chu Q, Qin S, Li G (1996) Anatomic structure on stems and leaves of short-bush plants of Pseudocerasus. Yantai Norm Univ J (Nat Sci Ed) 12:225-227

Yeh FC, Yang R-C, Boyle TBJ, Ye Z-H, Mao JX (1997) POPGENE, the user-friendly shareware for population genetic analysis. Molecular Biology and Biotechnology Centre, University of Alberta, Canada

Yu D-J, Li C-L (1986) Flora of China, vol 38. Science Press, Beijing

Zhang J-W, Bao M-Z (2007) Analysis of genetic diversity among Prunus mume cultivars via RAPD. J Beijing For Univ 29:54-58

Zhang FM, Ge S (2002) Data analysis in population genetics I. Analysis of RAPD data with AMOVA. Biodivers Sci 10:438-444 
Zhang X-P, Li X-H, Qiu Y-X (2006) Genetic diversity of the endangered species Kirengeshoma palmata (Saxifragaceae) in China. Biochem Syst Ecol 34:38-47. doi: 10.1016/j.bse.2005.05.007

Zhao Y-H, Guo Y-S, Zhou Y, Zhang K-C, Li Z-X, Wang L (2005) Preliminary study on the optimization of regeneration and genetic transformation of Chinese cherry (Prunus pseudocerasus Lindl. cv. Duiying). Plant Physiol Commun 41:770-772

Zietkiewicz E, Rafalski A, Labuda D (1994) Genome fingerprinting by simple sequence repeat (SSR)-anchored polymerase chain reaction amplification. Genomics 20: 176-183. doi:10.1006/geno.1994.1151 